\title{
The platform economy as a working opportunity for older people
}

\section{The case of the Hungarian carpooling company Oszkár}

\author{
Éva Berde
}

Department of Microeconomics, Corvinus University of Budapest, Budapest, Hungary and Demographic and Economic Research Center (Inside the School of Economics), Corvinus University of Budapest, Budapest, Hungary, and

\section{László Tőkés}

Department of Macroeconomics, Corvinus University of Budapest, Budapest, Hungary and Demographic and Economic Research Center (Inside the School of Economics), Corvinus University of Budapest, Budapest, Hungary.
Hungarian carpooling company Oszkár
Received 15 September 2019 Revised 27 September 2019 14 October 2019 Accepted 14 October 2019

\begin{abstract}
Purpose - The purpose of this paper is to show that gig jobs could be considered an alternative way, albeit not the very best, to give work opportunities to older people. This could offset the continuously decreasing income from the pay-as-you-go pension system, which remains the main source of income for older Hungarians.

Design/methodology/approach - The paper reviews the most important aspects of employment of older people and highlights the digital divide which still restricts their participation in the labor market. The paper analyzes data from the Hungarian carpooling company Oszkár and compares it with official statistical data from the Hungarian labor market, focusing on the dynamics of the employment of older persons.

Findings - The findings show that the alienation of older workers from the gig economy is just transitory, and that an increasing proportion of older gig workers can be anticipated.

Research limitations/implications - Compiling data on the gig economy faces a number of obstacles, as enterprises are disincentivized from revealing all their data.

Social implications - Older people are more likely to be employed in lower-quality jobs, such as ownaccount self-employed. They are also increasingly more likely to become gig workers.

Originality/value - The paper articulates the importance of remaining active as one ages and moreover challenges the traditional belief that gig jobs mainly offer opportunities to the younger generations.
\end{abstract}

Keywords Gig economy, Older labour market participants, Own-account self-employed

Paper type Research paper

\section{Introduction}

As populations age across Europe, North America and in many other parts of the world, these societies will face increasingly serious economic and social problems in the near future. Not

This research has been supported by the European Union and Hungary and co-financed by the European Social Fund through the project EFOP-3.6.2-16-2017-00017, titled "Sustainable, intelligent and inclusive regional and city models."

Journal of Enterprising : People and Places in the Global Economy (c) Emerald Publishing Limited $1750-6204$ DOI 10.1108/JEC-09-2019-0092 
only will it become more difficult to maintain the living standards of the very old (Nosraty et al., 2015), but also to keep those near retirement age in the labor market. In this paper we describe these trends, focusing on the European and Hungarian aspects, even though our literature survey uses relevant international research beyond Europe as well. The first part of this paper focuses on the working opportunities for older people and describes their acceptance in the workforce. We discuss self-employment, which is becoming more popular among older workers. We focus on a subgroup of the self-employed, those without employees, i.e. ownaccount self-employed workers (we will refer to them in most cases as own-account workers), which is a less beneficial form of employment. As a special realization of own-account working, gig jobs are also described in detail. We show that the underrepresentation of older persons in gig economies stems from the digital divide between age groups. This difference however is becoming less relevant in Hungary and across Europe and will presumably vanish completely in the near future. We also present a case study of the Hungarian carpooling company Oszkár. Data from the company shows that people over the age of 55 are willing to take on gig jobs. We also conduct a theoretical experiment using this data: considering the Oszkár labor market as an autonomous one, we compare its dynamics with the Hungarian labor market, focusing on workers in older age cohorts. Finally, we discuss and summarize our results.

\section{Pay-as-you-go old-age pension from Second World War till today}

The transition to work of the Western European baby boom generation (Newbold and Scott, 2017) 20-35 years after the Second World War created a sufficient labor force in those countries. Even though Hungary did not experience the same post-War phenomenon as in the West, the Ratkó era (Takács, 2013) saw a very similar demographic phenomenon: the number of births skyrocketed. Anna Ratkó was Minister of Social Welfare under the leadership of Mátyás Rákosi. One of her most important policies was to ban abortions, resulting in a significant increase in the Total Fertility Rate (TFR). Based on the data of the Human Fertility Database (Max Planck Institute for Demographic Research and Vienna Institute of Demography, 2019), the average TFR in Hungary between 1950 and 1956 was 2.67. It is an extremely high value considering Hungary's recent TFR figure of 1.45. Hungary's TFR in the 1950s rivalled those of France (2.75) and Finland (2.99), two countries with traditionally high TFRs. Hungary's TFR had dropped below 2 by 1961, whereas the same drop didn't occur in Finland until 1969, and in France by 1975 . Since then, even as these countries' TFRs fluctuated, they generally remained below 2, yet stayed significantly higher than Hungary's.

The high TFR figures, and their subsequent decline, had a significant effect on the economic growth rates of Western European economies for 20-35 years after the high-value period via the first demographic dividend (Bloom et al., 2003, 2009; Lee and Mason, 2006, 2010; Mason and Lee, 2004). Although the socialist regime hindered economic growth in Hungary, the pay-as-you-go old age pension became universal and available to everybody from 1975 (Augusztinovics and Köllo', 2009; Berde and Rigó, 2019). The high number of younger workers produced the resources to maintain the living standards of the small proportion of older people. The continuously decreasing TFR and the fact that the first demographic dividend was running out of breath did not just simply hinder economic growth, but also made it harder for European welfare countries to finance their pension systems. Moreover, not only did the economic fluctuations generate hardships, but life expectancy was also increasing, so more pensioners lived longer and continued to claim their pensions (Hudák et al., 2015). According to data from the World Bank's World Development Indicator Database (The World Bank, 2019) life expectancy in the European Union was 69.28 in 1960 and 80.99 in 2017. The same figures for Hungary are 68.00 in 1960 and 76.16 in 2017. 
The present and even more serious future unsustainability of the pay-as-you-go pension system in European welfare countries has been researched by many academics and policy makers. One of the most cited articles, a paper by Gruber and Wise (2005), forecasted these huge problems more than ten years ago. They showed that keeping people active in the labor market for a longer period can moderate the burdens that governments would face. Most recent papers also analyze the revenues and expenditures of the pension systems while researching the incentives. Börsch-Supan and Coile (2018) present a general overview of the financing opportunities of pension payments, while Nicolae and Ștefania (2018) describe the situation in Central and Eastern European countries. In addition, more and more papers are analyzing bridge jobs, which ensure the transition between work and pension, and can significantly extend people's working lives (Dingemans and Henkens, 2014; Giandrea et al., 2009; Ruhm, 1990).

European governments try to decrease the financial deficits of the pay-as-you-go pension system by using two main tools. On the one hand, many governments have discarded a defined benefit system, and have instigated a defined contribution system (Alonso-García et al., 2018). The essence of the latter is that pension contributions are still collected as a ratio of income, based on different predetermined rules, but pension payments are not pre-guaranteed, and are based on actual opportunities. Moreover, one can only apply for the pension if he or she has already contributed for a certain length of time and has also reached pension age. Hungary partially approaches this defined contribution system. On the other hand, governments often increase the retirement age, and eliminate early retirement options such as the disability pension and pre-pension unemployment benefits. The continuous changes to the retirement age for Hungarians with adequately long contribution periods is shown in Table I.

The introduction of a defined contribution system with the anticipatory demographic trends will result in the decrease of pension allowances, and the increase of retirement age means later retirement. These two phenomena create a push-effect, while an increase in people's years of good health results in a pull-effect (Milligan and Schirle, 2019). These two effects have undoubtedly affected the Hungarian system as well, and resulted in an increase of the employment ratio of older persons.

\section{Employment of older people}

Table II shows that employment ratio of 55- to 59-year-olds in Hungary increased sharply in recent years, and despite the low values at the beginning of the analyzed period it recently exceeded the EU28 figure. In the European Union, including Hungary, the employment ratio of 55- to 59-year-olds has overtaken that of 15- to 64-year-olds. Even though the employment ratio of 60- to 64-year-olds increased significantly in Hungary between 2002 and 2018 by almost 30 percentage points, it still lagged behind the European average.

Employment data of Table II shows that the effects of the "live longer, work longer" principle are becoming more apparent (Martin, 2018; Vodopivec and Dolenc, 2008). This paper will focus on the ways older people can stay in the workforce.

\begin{tabular}{lll}
\hline Year & Women & Men \\
\hline 1994 & 55 & 60 \\
1996 & 56 & 62 \\
2016 & 62 & 62 \\
2019 & 63.5 & 63.5 \\
2022 & 65 & 65
\end{tabular}

Source: Laws for retirement ages in Hungary
Hungarian carpooling company Oszkár 


\begin{tabular}{lccccccr}
\cline { 2 - 7 } JEC & Year & EU28: 15-64 & Hungary: 15-64 & EU28: 55-59 & Hungary: 55-59 & EU28: 60-64 & Hungary: 60-64 \\
\cline { 2 - 7 } & 2002 & 62.3 & 56.2 & 52.1 & 38.8 & 23.5 & 9.1 \\
& 2003 & 62.6 & 57 & 53.5 & 44.3 & 24.9 & 11.1 \\
& 2004 & 62.7 & 56.6 & 53.6 & 46 & 25.4 & 13.1 \\
& 2005 & 63.3 & 56.9 & 54.8 & 48.6 & 26.7 & 14.6 \\
& 2006 & 64.2 & 57.4 & 55.6 & 49.8 & 27.7 & 13.0 \\
& 2007 & 65.2 & 57 & 57.1 & 48.0 & 29.0 & 13.2 \\
& 2008 & 65.7 & 56.4 & 58.7 & 46 & 29.9 & 12.7 \\
& 2009 & 64.4 & 55.0 & 59.7 & 47.9 & 30.2 & 12.8 \\
Table II. & 2010 & 64.1 & 54.9 & 60.8 & 51.1 & 30.4 & 12.6 \\
Employment-to- & 2011 & 64.2 & 55.4 & 62.3 & 53.2 & 31.3 & 13.9 \\
population ratio, & 2012 & 64.1 & 56.7 & 63.8 & 55.1 & 32.6 & 13.8 \\
55-59 years old, and & 2015 & 64.1 & 58.1 & 64.7 & 57.7 & 34.4 & 15.5 \\
60-64 years old in & 2016 & 65.6 & 61.8 & 65.7 & 63.2 & 36.6 & 19.4 \\
Hungary and, in the & 2017 & 67.6 & 66.9 & 67 & 66.4 & 38.3 & 25.4 \\
EU28 countries & Source: & 68.6 & 68.2 & 70.3 & 70 & 40.5 & 32.2 \\
\hline & & 69.2 & 71.8 & 74 & 42.5 & 35.2 \\
\hline
\end{tabular}

The official attitude of national governments towards older people is apparent from their moves to increase the retirement age and from how they promote the advantages of remaining in the labor market and postponing retirement. Moreover, many European governments have introduced acts resembling the Age Discrimination Act of the United States of America, which aims to mitigate negative discrimination against older workers.

Unfortunately, despite the continuing efforts of governments, age discrimination in the workplace still affects the hiring of those over 55 years. As a survey reported by Carlstedt et al. (2018) shows, employers are reluctant to take on older people; they are more likely to look for younger employees. According to a recent paper (van Dalen et al., 2019) employers object to the raising of the retirement age, mostly in the construction industry, but also in other work sectors where hard physical effort is needed. Employers believe that older workers cannot match the physical effort of their younger co-workers. There is a general trend for employers in these sectors to take on older workers only when there is a scarcity of labor.

Neumark and Stock (1999) and Adams (2002) state that laws against age discrimination unequivocally protect older workers from being laid off. On the other hand, these laws also disincentivize employers to hire older workers because it is harder to fire them. Daniel and Heywood (2007) showed that anti-discrimination regulations create hidden unemployment. Employers are reluctant to employ older people just because of the laws. The continuous refusal of employment discourages older workers who then abandon the job market. If they stop seeking employment they cannot really be called unemployed even if they would still like to work.

The stereotypical view that older workers are not interested in developing their skills and abilities (Fritzsche and Marcus, 2013), are not capable of high-quality work due to diminishing physical and cognitive skills ( $\mathrm{Ng}$ and Feldman, 2012), and are inflexible (Fritzsche and Marcus, 2013), are so commonplace that they hinder the hiring of older workers, even in cases when a job does not need physical strength. Dordoni and Argentero (2015) mention many beliefs resulting in age discrimination. Gruber et al. (2009) describe why former governments thought that retiring older workers would create job opportunities for younger ones. Such discriminatory views has become so widely accepted in modern 
societies that even older workers themselves hold these beliefs. Berde (2019) showed that older workers fear age discrimination, so they will conceal their year of birth if they can.

In summary, the social acceptance of older workers in Europe is contradictory. While governments, particularly over the past 10-15 years, want to increase the retirement age, society itself is reluctant to accept this, especially employers, who usually try to avoid hiring older workers. In such circumstances self-employment is becoming an increasingly important solution for older people.

\section{Forms of employment for older people}

In many European countries, especially Hungary, the most important and possibly for many the only way to cover the cost of living after retirement is with pay-as-you-go pension benefits (Määttänen et al., 2014). Past reforms and proposed changes to the pension system make this kind of income source very uncertain. Future pensioners will get access to their pay-as-you-go pension benefits later in life, and the amount could be insufficient. Moreover, the jobs taken throughout one's working life are becoming more intermittent (Weil, 2014), and the length of working periods registered in the social security system is decreasing, thus making one's personal pension fund smaller. This may not be the case for those older workers with stable jobs and good health, as they can go on working and earning. On the other hand, an older person whose job is eliminated or who is forced to seek alternative work due to health problems faces serious problems. As it is getting harder for older people to remain "standard" employees, they need to look for alternative forms of work.

Following the definition of Hall and Krueger (2018) the following categories should be considered 'alternative workers': freelancers, casual workers, contract workers, help agency workers, independent contractors and the new self-employed. Not all these categories exist in all European countries, moreover some countries also define other categories which are similar to these. One example is in the United Kingdom, where some employment agencies find temporary work for highly-qualified professionals. There is also a very special form of alternative jobs: independent contractors and freelancers who do their gig jobs via platforms.

The self-employed category had always existed in Europe, and thanks to adequate regulations, the self-employed have always enjoyed almost the same rights in all areas of social security welfare as all workers in Hungary. Blanchflower (2000) also mentions that self-employed persons are more satisfied with their jobs than the average worker. Manyika et al. (2016) classify the self-employed, or independent workers as they call them, into four subcategories. Two of the four types choose to be part- or full-time self-employed on their own initiative - they are the "Casual earners" and "Free agents." The other two types, the "Financially strapped" and the "Reluctant" workers become self-employed involuntarily, as no other opportunities are available for them.

Buschoff and Schmidt (2009) focus not on traditional self-employed workers, but on ownaccount self-employed workers. They call own-account workers the new type of the selfemployed workers without employees, and they also show that these workers, based on the characteristics of their job, can be classed somewhere between the employee and selfemployed category. Own-account workers can generally decide whether they accept a task or not. Although, once they have accepted a job, they should complete its tasks as instructed by the principal, as is the case in a standard job by the boss. However, the own-account worker is not guaranteed continuous work and has to cover most of the labor costs that would normally be covered by the employer in most cases. Social benefits guaranteed to typical employees are only partly allocated to own-accountant workers, if at all. The appearance of non-standard jobs blurs the dividing lines between labor law and commercial 
law in many cases. In the past labor laws were imposed on workers, and other areas of business were regulated mainly by commercial laws. However, most own-account workers are not regulated by labor laws, only by commercial laws, and they are almost as vulnerable as Uber's driver-partners as described by Katz and Krueger (2019).

Eurostat reports data on own-account workers, although this is not necessarily a new type of individual entrepreneur. In reality, a self-employed person without employees is not totally the same as an own-account worker. For example, in Hungary a self-employed worker can have an individual entrepreneur certificate, and so has to pay a social contribution even if he or she does not have employees. Moreover, the Hungarian government created such new statuses of self-employed workers so that they could pay less contributions, but this also means they are guaranteed less benefits in the future. The Hungarian practice also defines a private individual with a tax number (source: brochures from the Hungarian National Tax and Customs Administration) which is identical with Buschoff and Schmidt's (2009) own-account workers. The working opportunities for private individuals with tax numbers are tightly restricted, and they have to pay all the contributions themselves. As far as we know, most post-socialist countries have this arrangement, although it appears that no academic paper has been published dealing with this question.

Alternative workers are considered to be self-employed workers. However, there were attempts to define alternative workers, see for example Manyika et al. (2016), but reverse induction is more prevalent in the literature. Researchers try to estimate the number of alternative workers based on the number and age composition self-employed workers. Johnes (2019) for example uses the proportion of self-employed workers to all employees as an indicator variable for measuring the proportion of gig workers in the United Kingdom.

Button (2019), Katz and Krueger (2017), Katz and Krueger (2019) and Ratten (2019) describe the trends in becoming self-employed in the case of older people. Eurostat publishes data on own-account workers throughout the European Union, although its definition does not cover all alternative workers, and as we stated earlier, not all own-account workers belong to the "critical" worker categories. In any case, these are the only available data for analysis, and they highlight at least some of the hardships of finding work.

The opportunity to get involved in own-account jobs could be advantageous and disadvantageous as well for older workers. Those who get higher pension benefits could supplement their income with own-account jobs - which could also become bridge jobs. However, most of those who cannot retire because of economic necessity are forced to accept poor-quality, badly-paid jobs. As Lain et al. (2018) observe, politicians often state that older workers can freely decide which work to take and when to retire. On the other hand, Lain et al. (2018) also cite Standing (2011), who states that a growing number of older workers are being pushed into a precariat group: they are forced to work further into their old age, and can only choose from a limited number of jobs, many of which are of poor-quality.

Lain et al. (2018) note that older workers in some English-speaking countries were forced to retire when they reached a certain age despite their desire to continue working. The abolition of compulsory retirement in the United States, United Kingdom, Canada, Australia and New Zealand changed this situation. Older people can now remain active in the labor market. However, this freedom of choice has produced other new exigencies as a result of labor market trends. Many older employees have not reached the necessary length of service required for pension benefits, and even if they have, they are entitled to only a small amount. So they are forced to remain active in the labor market. Employees often offer them poorquality jobs with low wages, which they have no choice but to accept. Moreover, if they 
cannot get any such jobs, they have to create opportunities for themselves: this is the time when they become self-employed, and in most cases own-account workers.

A burgeoning form of own-account worker is the gig worker. Gig workers may be highly qualified individuals who fill expert roles or unqualified workers for monotonous, physical jobs. They are private individuals who periodically take on new short-term roles or tasks. These gig workers and their clients find each other via electronic platforms. The platforms mediate between them, and the gig workers pay a percentage of their income to the platform owners, typically 10 to 20 per cent.

Gig workers usually know how to use the simplest and most important internet applications. Many surveys (Gallo et al., 2006; Hall and Krueger, 2018; Manyika et al., 2016) indicate that older workers are underrepresented in gig jobs. These results contradict the fact that older workers are more likely to be self-employed and take on alternative jobs than younger workers. In the next part of our paper we present some data that shows that older persons still lag behind younger generations when it comes to internet usage. As a result, they are underrepresented in the gig labor market. As more older people become more adept at using the internet in the years to come, their participation in the gig economy is likely to increase.

\section{The digital divide}

In December 1995 only 0.4 per cent of the world's total population used the internet, a figure which grew to 58.4 per cent by June 2019 (internet World Stats, 2019). However, this is an average figure which deviates greatly across continents: the North American figure is over 90 per cent while the African figure is only 39.5 per cent. Europe lags behind North America only slightly, while Hungary's figure is around the European average. When comparing the figures across age groups, greater differences emerge. For example, comparing Hungarians aged 25 to 54 years with those aged 55 to 74 who use the internet at least once a week, 60 per cent more of the younger cohort did so in 2018, while across the EU the same comparison yields only 39 per cent. (Note: Data for 2019 is not available yet.)

The difference in the quantity and quality of internet usage between age groups creates a "digital divide," resulting in social and economic inequality. The term "digital divide" was first used by McConnaughey et al. (1998) to describe differences in internet usage among US firms and individuals. The term has been used since to describe differences between continents, regions, and also among demographic categories. If older people can access and use the internet, they could use it not just for social, recreational and health-related purposes but also for finding work.

Figure 1 characterizes internet usage in Hungary and across the EU. An internet user is defined as someone who has used the internet at least once in every week over a three-month period. Data was collected in representative surveys. Figure 1 shows that the number of internet users over 55 years of age is constantly growing, but still lags behind the number of younger (25-54-year-olds) users, both in Hungary and across the EU. If we look more closely at the data, the difference between 55- to 64-year-olds to those under 55 in Hungary in 2018 is less than 30 percentage points in 2018. As people age and move through these age cohorts, this apparent age bias will vanish. Moreover, anyone of any age who uses the internet can also find jobs with it. It is apparent that as more older people move into self-employment, it is more likely that they will get involved in the gig economy. In the next section we present a case study of the Hungarian carpooling company, Oszkár, which demonstrates that gig jobs are available also for older drivers. 
Figure 1.

The rate of EU28 and Hungarian internet users from the $25-54$ and 55-74 age groups who use the internet at least once a week

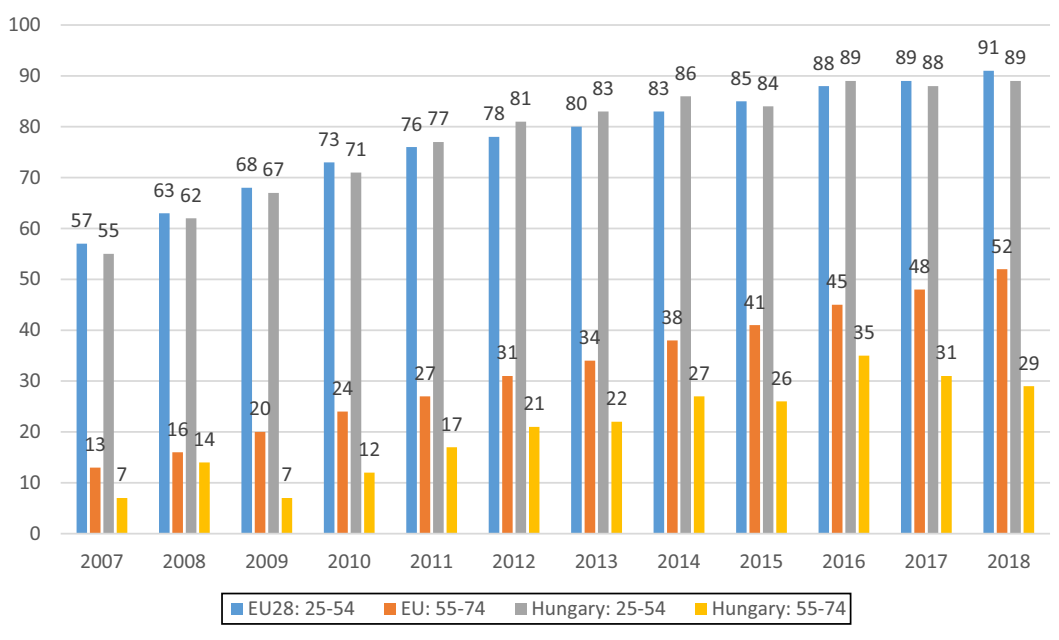

Source: Eurostat (2019)

\section{Older drivers and Oszkár}

Oszkár (Online Személyfuvar Közvetító Rendszer, literally: Online Passenger-lift Intermediary System), the Hungarian carpooling internet platform, was established in November 2007 by two Hungarian university students (source: www.oszkar.com). The platform reached its critical mass in 2013 (Economides and Himmelberg, 2013), and they now have around half a million registered users. This huge number of drivers and passengers (5 per cent of the total population of Hungary) has made them one of the most important players in the carpooling market in Hungary. Another important player is the France-based BlaBlaCar. Oszkár still functions today as a carpooling system, although it also acts as a profit-oriented business: it looks for professional drivers and offers them business packages. After observing the webpages of Oszkár (www.oszkar.com) for a month we found that about 30 to 40 per cent of the drivers applied for a business package which would allow them to offer rides for profit. The remaining drivers offer rides on planned journeys and only look for passengers who will share travel costs. More rides are offered by professional drivers. It is also apparent from the webpage that many non-professional drivers without business packages would also like to generate income, and not only to shrink their costs. In the following sections of this paper we do not distinguish between these groups of drivers because all their activities can be considered gig jobs, even if they generate different levels of income.

To use the Oszkár platform, either as a driver or a passenger, users must register by giving some personal data. Some information is compulsory, but date of birth remains optional, so it is only known for a large proportion of the registered users. Table III shows the average yearly age distribution of the registered drivers between 2013 and 2018.

The number of Oszkár drivers started to increase significantly in 2013 and since then has shown an increasing trend. The number of drivers was almost 4.5 times higher in 2018 than in 2013. The proportion of older drivers who gave their age increased from 1.9 to 3.5. The clear increase in the number of drivers can lead to similar conclusions as observed by Hall and Krueger (2018) about Uber drivers. They state that if the dynamics in the years 2012 to 2015 had continued in the same way, almost all US workers would have become Uber drivers in just a couple of years. Similarly, even though the trends showed by Table III are remarkable, not all Hungarian workers would become Oszkár drivers of course. 
One row in Table III shows that the proportion of drivers who did not give their date of birth decreased over the six years. If their ages were known, it might significantly affect the age distribution of the whole data set. One of the most plausible assumptions is that the distribution pattern of these drivers is the same as that of the drivers whose ages are known. The figures calculated using this assumption are presented in Table IV.

The increase in the proportion of older drivers in Table IV is slightly less than in Table III. However, it may be better to assume that the increase is actually higher. Berde (2019) shows using an online survey that 45.04 per cent of people aged 54 years or more would not give their ages when applying for a job via a platform. Using this result of this survey, we re-calculated the proportions and these figures are presented in Table V.

Table $\mathrm{V}$ shows a higher increase in the proportion of older drivers than Table III does, so it seems reasonable to conclude that the proportion of older drivers increased at an even faster pace than the skyrocketing number of all drivers. The phenomena described above can be characterized best in the words of Attila Prácser, Co-founder of Oszkár: "Oszkár is not just a sport for the young" (source: personal interview).

Observing Tables III-V, some important phenomena come to light. First, the number of active drivers increased rapidly: in 2013 the average per week was 847 (with a maximum of 1,352 ), increasing year by year up to 3,949 (with a maximum of 5,098 ) by 2018 . The number

\begin{tabular}{lrrrrrr}
\hline Proportion (percentage) & 2013 & 2014 & 2015 & 2016 & 2017 & 2018 \\
\hline Users aged 55 and over & 1.90 & 2.32 & 2.37 & 2.67 & 3.02 & 3.50 \\
Users aged 18-54 & 58.05 & 58.00 & 60.15 & 62.09 & 63.83 & 64.61 \\
Age unknown & 40.05 & 39.69 & 37.48 & 35.24 & 33.15 & 31.90 \\
Average number of active drivers per week & 847.1 & 1630.6 & 2521.1 & 3206.2 & 3732.2 & 3948.7
\end{tabular}

Notes: Numbers are the yearly averages of the weekly figures. The last row presents the yearly average of the number of active drivers per week

Source: Own calculations based on Oszkár data (received from the CEO of Oszkár)

Hungarian carpooling company Oszkár 
of drivers who made at least one trip during any week increased almost fivefold over these six years.

The second important fact is that the number of drivers over 55 also skyrocketed by a factor of more than eight, from an average of 16 in 2013 (with a maximum of 27), to 138 in 2018 (with a maximum of 174). Using the assumptions for Table V, the averages become 29 in 2013 and 252 in 2018.

In the last part of this section we present a theoretical experiment: we simulate the Oszkár labor market and compare it with the real Hungarian labor market. Analyzing the dynamics of these two labor markets, we show how the employment of those over 55 years of age developed between 2013 and 2018. First, some definitions are needed to understand the essence of this simulation:

Standard employment rate for a given age group: We use the standard statistical definition, i.e. the number of employed people of a particular age as a percentage of the total number of people in the same age group.

Imputed Oszkár employment ratio: The number of Oszkár drivers of a particular age group as a percentage of the total number of Oszkár drivers. The calculation uses some unpublished results from the survey described in Berde (2019). As stated earlier, the survey asked participants whether they would give their ages when applying for a gig job. The answers from those 136 respondents aged between 55 and 69 years are presented in Table VI.

Using the information of Table VI we distributed the drivers of unknown age into the different age groups. Based on the number of different cohorts of drivers in the following simulation we use the data of 2013 as a reference point. So, we normalize both the standard employment rate and the imputed Oszkár employment ratios to 100 in 2013, and all the other figures are recalculated according to this. It makes possible to get rid of the level effects and concentrate to the trend dynamics. Figure 2 contains the results.

Panel A of Figure 2(a) clearly states that the level of the imputed Oszkár employment ratio was always higher than the standard employment ratio relatively to their 2003-based reference value. Moreover, not just the levels, but the growth rates were also higher for the imputed Oszkár employment ratio in almost all years, except from 2014 to 2015. This phenomenon reinforces the message of Tables III-V: older workers are more open to gig jobs than the whole population. In the other panels of Figure 2 we analyze narrower age cohorts. Here we should articulate again that the proportion of drivers of unknown age is significant, and we classified them based on the results of a survey with a small sample, so the results should be treated with caution - even if they show strong trends.

Panel B of Figure 2(b) shows the same data as Panel A, but restricts the sample to the 55-59 age cohort. This figure sheds light on the cause of one of the important phenomena shown in Panel A: the drop in the increase of the imputed Oszkár employment ratio between 2014 and 2015 was partly due to the decrease of the same ratio for the 55-59 age cohort.

Table VI.

Proportion of respondents who would not give their ages when applying for a gig job

\begin{tabular}{lcc}
\hline Age & No. of respondents & Proportion of respondents would not give their ages \\
\hline $55-59$ & 58 & 38 \\
$60-64$ & 60 & 50 \\
$65-69$ & 18 & 51
\end{tabular}

Source: Berde (2019) 


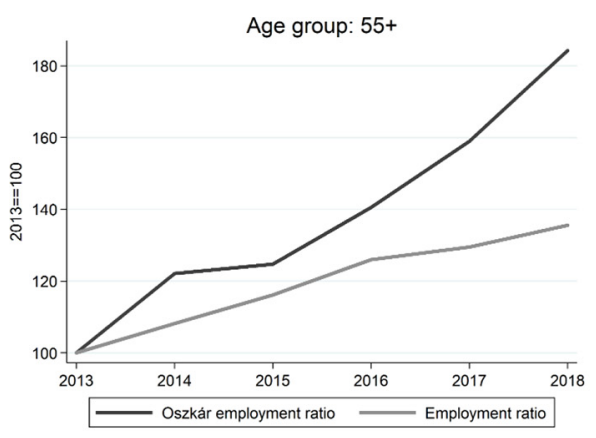

(a)

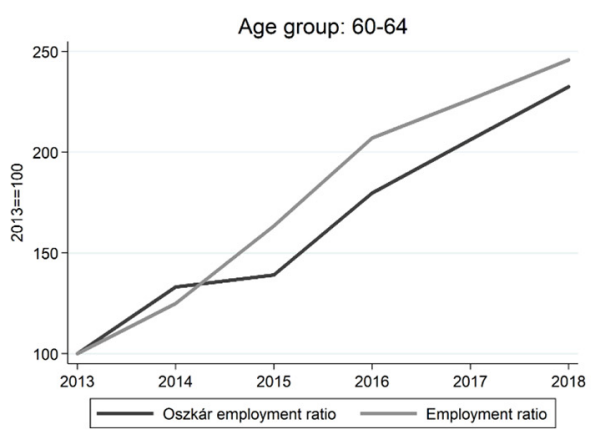

(c)

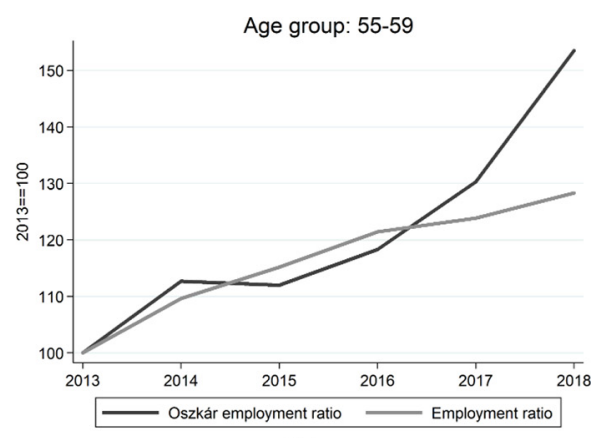

(b)

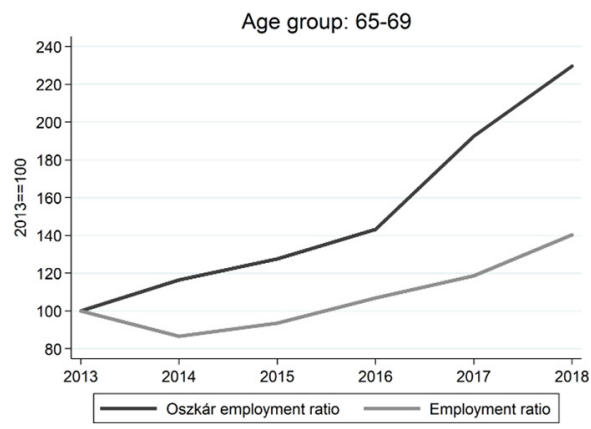

(d)
Figure 2. Employment ratio dynamics for the older age cohorts

Notes: (a) Panel A; (b) Panel B; (c) Panel C; (d) Panel D
Source: Hungarian Central Statistical Office, and the authors' own calculations

Panel C of Figure 2(c) shows that there was a bigger increase in the imputed Oszkár employment ratio from 2013 to 2014 for the 60-64 age group, which was followed by a much smaller increase than in the case of the standard employment ratio. After that the two growth rates were similar to each other, but the imputed Oszkár employment ratio was not able to make up for its lagging behind.

Panel D of Figure 2(d) shows that the relative size of the imputed Oszkár ratio was higher than the standard employment ratio for the age group 65-69 in all analyzed years. The growth rate of the imputed Oszkár employment ratio was also higher in most of the years, most significantly from 2013 to 2014, when the standard employment ratio decreased, and from 2016 to 2017. It is important to note that the number of the drivers in this particular age cohort is really low, so these results should not be considered robust.

In conclusion, although the data presented in Figure 2 is not so robust, it suggests that the probability that older drivers will join Oszkár will increase in the near future.

\section{Conclusions}

Our paper draws attention to the fact that due to low total fertility rates and increasing life expectancy, pay-as-you-go pension systems all around Europe, including Hungary, have become financially unsustainable. We also showed that governments try to solve this serious 
issue by increasing the retirement age and decreasing pension benefits for individuals. Due to these policies, older people cannot fully rely on the pay-as-you go pension system, which has been their main source of income in Hungary so far. Consequently, older people are forced to stay active in the labor market for longer periods than they had before.

Remaining active in the labor market is not so easy for older workers as age discrimination exists in many societies. Employers are reluctant to hire older workers, even they could carry out the work. Employers prefer younger applicants if there are any. The result is that older people feel the need to create work opportunities for themselves, and unfortunately this can mean poor-quality alternative jobs such as own-account jobs. A specific type of these kinds of jobs are the gig jobs.

We also presented evidence that according to the literature gig jobs which are presumably managed via the internet are not so popular among older workers. We showed that the basic cause of this phenomenon is the differences in internet usage: older persons are less likely to use the internet than younger people. However, this difference is rapidly decreasing in Hungary, so we can expect that the proportion of internet users will soon be above 90 per cent, irrespective of age categories. This means that the relevance of gig jobs will suddenly increase among both younger and older people.

Using data from the Hungarian carpooling company Oszkár we showed that there are still areas where the number of older gig workers is increasing faster than the number of younger ones. The results of our simulation suggest that the labor market for older Oszkár drivers developed faster than the real Hungarian labor market. This is still true despite the fact that the economic activity of older generations has increased a lot in the past ten years. Of course, not all workers over 54 can become Oszkár drivers, so the trend is expected to level off. The example of older Oszkár drivers shows that gig jobs are not only for younger adults. As gig jobs are precarious, they cannot fully solve the issues stemming from the aging of the population and the problems faced by older workers, but they can provide an income for some of them.

\section{References}

Adams, S.J. (2002), "Passed over for promotion because of age: an empirical analysis of the consequences", Journal of Labor Research, Vol. 23 No. 3, pp. 447-461.

Alonso-García, J., Boado-Penas, M. D C. and Devolder, P. (2018), “Adequacy, fairness and sustainability of pay-as-you-go-pension-systems: defined benefit versus defined contribution", The European Journal of Finance, Vol. 24 No. 13, pp. 1100-1122.

Augusztinovics, M. and Köllo, J. (2009), "Decreased employment and pensions: the case of Hungary”, in Holzmann, R., MacKellar, L. and Repansek, J. (Eds), Pension Reform in Southeastern Europe, pp. 89-105.

Berde, É. (2019), “Older people in the platform economy”, Frontiers in Sociology, Vol. 4, p. 8.

Berde, É. and Rigó, M. (2019), "Job satisfaction at older ages: a comparative analysis of Hungarian and German data", Zeitschrift Fur Gerontologie Und Geriatrie, doi: 10.1007/s00391-019-01547-x.

Blanchflower, D.G. (2000), "Self-employment in OECD countries", Labour Economics, Vol. 7 No. 5, pp. 471-505.

Bloom, D.E., Canning, D., Fink, G. and Finlay, J.E. (2009), "Fertility, female labor force participation, and the demographic dividend", Journal of Economic Growth, Vol. 14 No. 2, pp. 79-101.

Bloom, D., Canning, D. and Sevilla, J. (2003), The Demographic Dividend: A New Perspective on the Economic Consequences of Population Change, Rand Corporation, Santa Monica, CA.

Börsch-Supan, A.H. and and Coile, C. (2018), "Social security programs and retirement around the world: reforms and retirement incentives - introduction and summary", Working Paper No. 25280, National Bureau of Economic Research, Cambridge, MA, doi: 10.3386/w25280. 
Buschoff, K.S. and Schmidt, C. (2009), "Adapting labour law and social security to the needs of the "new self-employed' - comparing the UK, Germany and The Netherlands", Journal of European Social Policy, Vol. 19 No. 2, pp. 147-159.

Button, P. (2019), "Population aging, age discrimination, and age discrimination protections at the 50th anniversary of the age discrimination in employment act", Working Paper No. 25850, National Bureau of Economic Research, Cambridge, MA, November 2019.

Carlstedt, A.B., Brushammar, G., Bjursell, C., Nystedt, P. and Nilsson, G. (2018), “A scoping review of the incentives for a prolonged work life after pensionable age and the importance of "bridge employment", Work, Vol. 60 No. 2, pp. 175-189.

Daniel, K. and Heywood, J.S. (2007), “The determinants of hiring older workers: UK evidence”, Labour Economics, Vol. 14 No. 1, pp. 35-51.

Dingemans, E. and Henkens, K. (2014), "Involuntary retirement, bridge employment, and satisfaction with life: a longitudinal investigation”, Journal of Organizational Behavior, Vol. 35 No. 4, pp. 575-591.

Dordoni, P. and Argentero, P. (2015), "When age stereotypes are employment barriers: a conceptual analysis and a literature review on older workers stereotypes", Ageing International, Vol. 40 No. 4, pp. 393-412.

Economides, N. and Himmelberg, C. (2013), "Critical mass and network evolution in telecommunications", in Brock, G.W. (Ed.), Toward a Competitive Telecommunication Industry, Routledge, New York, NY, pp. 59-76.

Eurostat (2019), "Digital economy and society statistics - households and individuals - Statistics explained", available at: https:/ec.europa.eu/eurostat/statistics-explained/index.php/Digital_economy_ and_society_statistics_-_households_and_individuals (accessed 15 June 2019).

Fritzsche, B. and Marcus, J. (2013), "The senior discount: biases against older career changers: senior discount", Journal of Applied Social Psychology, Vol. 43 No. 2, pp. 350-362.

Gallo, W.T., Bradley, E.H., Dubin, J.A., Jones, R.N., Falba, T.A., Teng, H.-M. and Kasl, S.V. (2006), “The persistence of depressive symptoms in older workers who experience involuntary job loss: results from the health and retirement survey", The Journals of Gerontology Series B: Psychological Sciences and Social Sciences, Vol. 61 No. 4, pp. S221-S228.

Giandrea, M.D., Cahill, K.E. and Quinn, J.F. (2009), “Bridge jobs: a comparison across cohorts”, Research on Aging, Vol. 31 No. 5, pp. 549-576.

Gruber, J. and and Wise, D. (2005), "Social security programs and retirement around the world: fiscal implications, introduction and summary", Working Paper No. 11290, National Bureau of Economic Research, Cambridge, MA, doi: 10.3386/w11290.

Gruber, J., Milligan, K. and and Wise, D.A. (2009), "Social security programs and retirement around the world: the relationship to youth employment, introduction and summary", Working Paper No. 14647, National Bureau of Economic Research, Cambridge, MA, January 20009.

Hall, J.V. and Krueger, A.B. (2018), "An analysis of the labor market for Uber's driver-partners in the United States”, ILR Review, Vol. 71 No. 3, pp. 705-732.

Hudák, E., Varga, P. and Várpalotai, V. (2015), “The macroeconomic impacts of demographic changes in Hungary in the context of the European union", Financial and Economic Review, Vol. 14 No. 2, pp. 89-127.

Internet World Stats (2019), "Internet world stats - usage and population statistics", available at: www. internetworldstats.com/ (accessed 15 June 2019).

Johnes, G. (2019), "The gig economy in the UK: a regional perspective”, Journal of Global Responsibility, Vol. 10 No. 3, pp. 197-210.

Katz, L.F. and Krueger, A.B. (2017), "The role of unemployment in the rise in alternative work arrangements", American Economic Review, Vol. 107 No. 5, pp. 388-392. 
Katz, L.F. and Krueger, A.B. (2019), "The rise and nature of alternative work arrangements in the United States, 1995-2015”, ILR Review, Vol. 72 No. 2, pp. 382-416.

Lain, D., Airey, L., Loretto, W. and Vickerstaff, S. (2018), "Understanding older worker precarity: the intersecting domains of jobs, households and the welfare state", Ageing and Society, pp. 1-23.

Lee, R. and Mason, A. (2006), "What is the demographic dividend?", Finance and Development, Vol. 43 No. 3, p. 16.

Lee, R. and Mason, A. (2010), "Fertility, human capital, and economic growth over the demographic transition", European Journal of Population/Revue Européenne de Démographie, Vol. 26 No. 2, pp. 159-182.

McConnaughey, J., Lader, W. and Chin, R. (1998), "Falling through the net II: new data on the digital divide', National Telecommunications and Information Administration", Department of Commerce, US Government, Washington, DC.

Määttänen, N., Võrk, A., Piirits, M., Gal, R.I., Jarocinska, E., Ruzik, A. and Nijman, T. (2014), "The impact of living and working longer on pension income in five European countries: Estonia, Finland, Hungary, The Netherlands and Poland”, Working paper No. 08/2014-036, Netspar, Tilburg.

Manyika, J., Lund, S., Bughin, J., Robinson, K., Mischke, J. and Mahajan, D. (2016), "Independent work: choice, necessity, and the gig economy”, McKinsey Global Institute, Vol. 2016, pp. 1-16.

Martin, J.P. (2018), "Live longer, work longer: the changing nature of the labour market for older workers in OECD countries", Working paper No 11510, IZA, Bonn.

Mason, A. and Lee, S.-H. (2004), "The demographic dividend and poverty reduction", Seminar on the Relevance of Population Aspects for the Achievement of the Millennium Development Goals, New York, NY, November 2004.

Max Planck Institute for Demographic Research (Germany and Vienna Institute of Demography (Austria) (2019), "Human fertility database", available at: www.Humanfertility.Org or available at: www.humanfertility.org/cgi-bin/agreement.php (accessed 11 September 2019).

Milligan, K. and Schirle, T. (2019), "Push and pull: Disability insurance, regional labor markets, and benefit generosity in Canada and the United States", Journal of Labor Economics, Vol. 37 No. S2, pp. S289-S323.

Neumark, D. and Stock, W.A. (1999), “Age discrimination laws and labor market efficiency”, Journal of Political Economy, Vol. 107 No. 5, pp. 1081-1125.

Newbold, K.B. and Scott, D.M. (2017), "Driving over the life course: the automobility of Canada's millennial, generation X, baby boomer and greatest generations", Travel Behaviour and Society, Vol. 6, pp. 57-63.

Ng, T.W. and Feldman, D.C. (2012), "Evaluating six common stereotypes about older workers with meta-analytical data", Personnel Psychology, Vol. 65 No. 4, pp. 821-858.

Nicolae, B. and Stefania, A.J. (2018), "Considerations regarding the pension systems in countries of Central and Eastern Europe”, Romania, Vol. 63 No. 65, p. 15.

Nosraty, L., Jylhä, M., Raittila, T. and Lumme-Sandt, K. (2015), "Perceptions by the oldest old of successful aging, vitality 90+ study", Journal of Aging Studies, Vol. 32, pp. 50-58.

Ratten, V. (2019), "Older entrepreneurship: a literature review and research agenda", Journal of Enterprising Communities: People and Places in the Global Economy, Vol. 13 Nos 1/2, pp. 178-195.

Ruhm, C.J. (1990), "Bridge jobs and partial retirement”, Journal of Labor Economics, Vol. 8 No. 4, pp. 482-501.

Standing, G. (2011), The Precariat: The New Dangerous Class, Bloomsbury Academic, London, New York, NY.

Takács, J. (2013), "Unattainable desires? Childbearing capabilities in early 21st-Century Hungary", Childbearing, Women's Employment and Work-Life Balance Policies in Contemporary Europe, Springer, pp. 179-206. 
The World Bank (2019), "Life expectancy at birth, total (years), World Bank data", available at: https:// data.worldbank.org/indicator/sp.dyn.le00.in (accessed 14 September 2019).

van Dalen, H.P., Henkens, K. and Oude Mulders, J. (2019), "Increasing the public pension age: Employers' concerns and policy preferences”, Work, Aging and Retirement.

Vodopivec, M. and Dolenc, P. (2008), "Live longer, work longer: making it happen in the labor market", Financial Theory and Practice, Vol. 32 No. 1, pp. 65-81.

Hungarian carpooling company Oszkár

Weil, D. (2014), The Fissured Workplace, Harvard University Press, Cambridge.

\section{Corresponding author}

Éva Berde can be contacted at: eva.berde@uni-corvinus.hu

For instructions on how to order reprints of this article, please visit our website: www.emeraldgrouppublishing.com/licensing/reprints.htm Or contact us for further details: permissions@emeraldinsight.com 